\title{
New Zealand's Experiment in Tax Neutrality for Retirement Saving
}

\author{
Susan St. John \\ Department of Economics, University of Auckland Business School, The University of Auckland, \\ Commerce A Building, Private Bag 92019, Auckland Mail Centre, Auckland 1142, New Zealand. \\ E-mail: s.stjohn@auckland.ac.nz
}

Reforms in the late 1980s made the New Zealand system of retirement income policies unique among developed countries. For nearly 20 years the system comprised just a universal state pension, and voluntary unsubsidised private saving. Tax concessions, as is traditional in other countries, were abandoned and the concept of tax neutrality for saving promoted in the context of other wide-ranging reforms to the tax system. This paper examines how New Zealand was able to achieve this radical tax change and sustain it. Strident calls to promote saving for retirement gradually undermined the accord around tax neutrality, bringing the 20 -year experiment to an end in 2007. The reintroduction of tax incentives for certain types of saving, and other types of state intervention in private provision has implications for the future of New Zealand's unique retirement system.

The Geneva Papers (2007) 32, 532-552. doi:10.1057/palgrave.gpp.2510142

Keywords: tax neutrality; tax concessions; retirement saving; annuities; retirement policies

\section{Introduction}

In the late 1980s, New Zealand initiated far-reaching reforms to retirement income policy that made the New Zealand model unique among developed countries. For nearly 20 years the system comprised just a universal state pension, called New Zealand Superannuation (NZS), and voluntary unsubsidised private saving. ${ }^{1}$ These arrangements ensured a cost-effective, secure, equitable and sustainable basic income for all in an uncertain future. The decision in the late 1980s to promote tax neutrality for saving in the context of wide-ranging reforms to the tax system was critical to this success. While the 20-year experiment is coming to an end, this paper examines how New Zealand was able to achieve this radical tax change and sustain it until 2007.

The paper first outlines the nature of public and private provision so that the tax treatment of private provision can be seen in the context of the entire retirement package. The background to the neutral tax treatment of retirement saving is reviewed, including a brief account of the difficulties of transition to tax neutrality. Strident calls to promote saving for retirement gradually undermined the accord around tax neutrality in the 2000s, leading in 2007 to the reintroduction of tax incentives for certain types of saving, and other types of state intervention in private provision.

\footnotetext{
${ }^{1}$ For a historical description, see Preston (2001).
} 


\section{Retirement income provision in New Zealand}

\section{Public provision}

The state pension, NZS, as set out in Part 1 of the New Zealand Superannuation and Retirement Income Act 2001, enjoys wide political support. NZS is payable at age 65 years to all New Zealanders living in New Zealand who meet the minimal residency requirements of 10 years' residency since the age of 20 years and not less than 5 years' residency since attaining the age of 50 .

The net rate of payment for a couple is legislated to be within the band of 65 and 72.5 per cent of net Average Ordinary Time Weekly Earnings (AWE). For each married person this means a guaranteed floor of 32.5 per cent of AWE. Each year there is an annual adjustment to reflect movements in the Consumer Price Index, unless the floor of 65 per cent is breached at which point wage indexation restores the floor. The rate for a single pensioner who shares accommodation is 60 per cent of the married rate, or 39 per cent of AWE. The rate for pensioners living alone is 65 per cent of the married rate or 42.3 per cent of AWE. Each person is taxed in their own right as an individual on total gross income including the gross pension, so that with mildly progressive income tax rates (see Table 2), the top-income pensioner effectively receives a pension worth approximately 70 per cent of the pension of the lowest income pensioner.

The attractive and unusual features of NZS from the perspective of the individual are as follows:

- The pension is non-contributory and thus recognises both paid and unpaid contributions to society. Women in particular have gained. ${ }^{2}$

- Each person over 65 is treated as an individual and receives the pension in his or her own right. While there are different rates depending on marital status, no account is taken of a spouse's income.

- The payment is indexed to living standards by the provision of a floor related to average wages so that protection is afforded not only for inflation but also for a growth in living standards generally.

- The pension protects against hardship with those over 65 enjoying the best profile of living standards of any age group. ${ }^{3}$

- The pension protects against the longevity risk.

- The pension is very simple to understand and apply for. There are no income or asset tests that affect the entitlement.

From the perspective of society there are also advantages, as follows:

- As social insurance, the scheme does not require any guarantee period or return of capital on death.

- The general tax base is wider than wage income, as it includes taxes on investment income and on consumption. Thus some of the burden of the PAYG scheme is spread from the working age population to include tax contributions from the old as well.

\footnotetext{
${ }^{2}$ See St. John and Gran (2001).

${ }^{3}$ Ministry of Social Development (2006).
} 
- The level has been effective in largely preventing poverty for the elderly, so that there is little need for supplementary welfare payments.

- Administration costs are minimised and there are no inherent disincentives to work or save because the pension is not means tested.

In terms of sustainability, the net cost of paying NZS is currently 3.6 per cent of GDP and expected to increase to around 7.5-8 per cent of GDP by $2051 .{ }^{4}$ While the fiscal pressures of an ageing population are real, the size of the problem seems modest in comparison with other OECD (Organization for Economic Cooperation Development) countries many of whom already face much higher pension/GDP ratios. It must also be remembered that other countries provide subsidies in the form of tax expenditures for private provision that are not reflected in pension/GDP ratios. Ireland for example has a regime of tax expenditure for retirement incomes that if counted as part of the state's pension costs for 2000/2001 would increase the pension/ GDP ratio by 1.7 percentage points. ${ }^{5}$

Thus it may be argued that the lack of tax incentives has made the relatively generous tax-funded universal NZS affordable. The New Zealand Government also partly prefunds this pension by setting aside part of the fiscal surplus each year to provide a buffer against the projected increase in taxation. ${ }^{6}$

\section{Private provision}

New Zealand has had a uniquely simple system of voluntary, unsubsidised supplementary provision for retirement saving. In theory, people have been free to save in any appropriate way, whether that be in acquiring equity in housing, repaying debt, investing in businesses or financial assets or even in furthering their own education or that of their children. This next section discusses the context of the tax reforms in New Zealand that gave rise to this system.

As in other countries, employment-based defined contribution superannuation schemes ${ }^{7}$ have been steadily replacing defined benefit schemes as risk is shifted from employers to employees, and overall employer participation has declined. The taxneutral treatment of superannuation saving has been an additional negative factor impacting on private pension and annuity provision in New Zealand with the result that fewer people than in the past now come into retirement with either an annuity or a private pension to supplement the basic state pension.

\section{An assessment}

For New Zealanders of modest means and with limited lifetime earnings, NZS provides a replacement income, sufficient in most cases to keep them out of the poverty statistics. Using the Ministry of Social Development's definition of the

\footnotetext{
${ }^{4}$ See http://www.retirement.org.nz/.

${ }^{5}$ Hughes (2005).

${ }^{6}$ St. John (2005).

${ }^{7}$ Superannuation refers to retirement saving whether in the form of a pension or lump sum.
} 
poverty line (60 per cent of median disposable household income after housing costs), just over 50 per cent of households supported by an income-tested benefit are in poverty but only 7.6 per cent of those reliant on NZS. ${ }^{8}$

For the few who do experience hardship, and there will always be some, especially when there are ill-health and housing problems, poverty is not higher among women than men. ${ }^{9}$ This is in stark contrast to the U.K. pensioner poverty picture where one in five is under the poverty line and women are disproportionately affected. A similar picture emerges for Ireland, where pensioner poverty is higher than for the population as a whole and higher again for pensioner women. ${ }^{10}$

From time to time, the New Zealand model has been considered in international debate, but more as an object of curiosity than as a model to be emulated. ${ }^{11}$ The New Zealand model may however offer a credible alternative to the three-pillar World Bank model. ${ }^{12}$ The first tier universal pension together with the tax-neutral regime for private financial saving has cost advantages and favourable equity implications, and enjoys relative simplicity. If there is a gap, it is in the lack of assistance to enable middle-income people to achieve an adequate income replacement rate that offers them protection from increasing average longevity. ${ }^{13}$

\section{Tax reform 1987-1990}

The tax system of the early 1980s was widely perceived to be complex and distortionary. In December 1987, Roger Douglas, the Minister of Finance, announced there would be a flat rate of personal tax aligned with the company rate. Tax subsidies for saving were to be removed, and the tax base broadened by the closure of loopholes of all kinds. The rationale was largely economic and there did not appear to be any particular concerns about the effects on retirement incomes. The intent was to "level the playing field" so as to remove, or minimise, the economic cost of distortions that arose from treating different income streams differently. Douglas argued that tax concessions had allowed savings to flow to favoured financial institutions that had not necessarily invested the money in the best ways possible for growth. He claimed that a low, flat tax rate was necessary to encourage saving, reward work and minimise avenues for income splitting. The intent was clearly to underpin the other economic reforms of the 1980s in New Zealand that had emphasised the role of the free market in the allocation of scarce resources. ${ }^{14} \mathrm{He}$ also argued that a flat rate would prevent taxation by stealth as inflation "pushes people into higher income tax brackets". 15

\footnotetext{
${ }^{8}$ Ministry of Social Development (2005).

${ }^{9}$ Fergusson et al. (2001).

${ }^{10}$ McCashin (2005).

${ }^{11}$ See, for example, Johnson (1999).

${ }^{12}$ St. John and Willmore (2001).

13 St. John (2006b).

${ }^{14}$ Easton (1997a, b).

${ }^{15}$ Douglas (1987).
} 
While flat tax itself is not progressive, improving fairness was another strong rationale for the changes. Tax avoidance and tax exemptions had rendered the old tax system of the 1980s far less progressive than the stepped up marginal schedule appeared:

[Flat tax] in conjunction with enhanced income support for low income people in the workforce and the abolition of tax concessions that favour the better-off will also make our tax-benefit system more truly progressive. ${ }^{16}$

Higher income people under flat tax would pay more tax, first because they would no longer benefit from a lower rate on the first part of their income and second because of the removal of the major tax concessions and the closing of tax loopholes. The Minister of Finance claimed that the concessions on life insurance and superannuation schemes alone were worth 2.5 percentage points on basic tax rates. The cost of these concessions was estimated to represent about 1.2 per cent of GDP. ${ }^{17}$

The rate of the flat tax was not announced in the tax package although later it was revealed that a 23 per cent rate was contemplated and would have been accompanied by the cuts to government expenditure by the introduction of user pays for state provision of many kinds.

\section{Saving for retirement}

As in many other countries, tax-subsidised private pensions were originally the preserve of employees in large companies and the government sector. The chief beneficiaries in the private sector were characteristically white, male, high-income, long-term employees. In the state sector, a defined benefit scheme (The Government Superannuation Fund (GSF)) with its inflation-adjusted pensions enjoyed wide coverage in the 1960s and 1970s.

Prior to the tax reforms of the late 1980s, pension schemes had received preferential tax treatment on both employee and employer contributions and on fund earnings (see Box 2). While pensions were taxed as income, up to 25 per cent of pension savings in these schemes could be taken as a tax-free lump sum. Pure lump-sum schemes were also tax subsidised, but less generously since the early 1980s. ${ }^{18}$

Under the tax regime introduced in 1987 and applying until 2007, contributions to savings plans are made out of after-tax income so that contributions may be described as "taxed" (T). Income accruing as fund earnings is taxed (T) at the company rate of 33 per cent, while withdrawals from the fund are exempt from tax (E). The traditional expenditure tax treatment involves an Exempt/Exempt/Taxed (EET) regime while the New Zealand income tax treatment of savings involved a Taxed/Taxed/Exempt (TTE) regime (see Table 1).

By 1 April 1990, the new tax regime was fully operational with the Income Tax Amendment Act 1989 and the Superannuation Schemes Act 1989 providing the

\footnotetext{
${ }^{16} \mathrm{Ibid}$.

${ }^{17}$ Ibid.

${ }^{18}$ For a discussion of the pre-reform tax treatment, see St. John and Ashton (1993, pp. 23-24).
} 
Table 1 Different tax treatments of superannuation

\begin{tabular}{lll}
\hline & Expenditure tax treatment & Income tax treatment \\
\hline Contributions & Exempt & Taxed \\
Investment income & Exempt & Taxed \\
Withdrawals & Taxed & Exempt \\
& EET & TTE \\
\hline
\end{tabular}

Note: The EET is the traditional treatment of pensions.

necessary taxation and supervisory legislation. Schemes became "registered" by the Government Actuary rather than "approved" as previously for tax concession purposes. The regime emphasised the responsibilities of trustees and applied equally to schemes sponsored by employers and those offered to the public via retail schemes.

From this point, New Zealand's tax regime for retirement income saving no longer distinguished between pension and lump-sum schemes. A tax-neutral approach precludes the right to regulate retirement saving for social purposes, for example, to legislate for the purchase of an annuity from the retiree's lump-sum savings. Thus with no tax concessions, no restrictions could apply as to how scheme benefits were to be received, although the trust deed could specify such details. Also there was no restriction on the amount of the employer's contribution. Rather than tight regulation, the disclosure requirements of the Securities Amendment Act 1996 and the Investment Advisors (Disclosure) Act 1996, were imposed, consistent with free market reforms that assume full information. ${ }^{19}$

These far-reaching reforms made New Zealand the only OECD country not to treat private savings for retirement differently from other forms of saving. While the intent of removing privileges from certain classes of saving was to encourage investment in more productive areas, the idea of tax neutrality in the treatment of saving was difficult to realise in practice as discussed below.

\section{The transition to tax neutrality}

A complex and uncertain time for private superannuation followed the December 1987 announcement. Arguments that changes to existing schemes involved retrospective legislation fell on deaf ears. The government could point to many other reforms undertaken in the 1980s that entailed a measure of retrospectivity. A transitional regime for previously tax-favoured schemes was supposed to be sufficient to allow the smooth adjustment to the new tax environment.

A consultative committee was set up under the chairmanship of Dr. Donald Brash to hear submissions. While the reforms themselves were not supposed to be up for debate, the overwhelming majority of submissions to the committee voiced strong opposition to the direction that the government had chosen. The Brash Committee was however in sympathy with the concept of neutral treatment of all forms of savings,

\footnotetext{
${ }^{19}$ Periodic Report Group (1997, p. 191).
} 
but recommended that an approach that exempted contributions from tax, fully taxed fund earnings and the emerging pension benefits EET would be more appropriate. ${ }^{20}$ Under certain assumptions, such a regime was tax neutral although the committee was in favour of some degree of concession, which they argued could be offset by a lower entitlement to the state pension. Among the arguments for this alternative treatment were

- lower windfall gains for existing pensioners and those close to retirement,

- less disruption to schemes in the short term with implications for the stability of capital markets,

- better ability to impose regulations, especially those relating to preservation, portability and the requirement to take a pension.

The committee claimed that the government's proposed TTE regime would be more fiscally costly than the equivalently neutral ETT regime that they recommended. This extra cost would arise despite the short-term gains that would accrue to the government's budget by bringing the tax liability forward to contributions. Not only would the possibility of increased numbers of schemes being wound up mean greater calls on the state pension in the future, but they also foresaw the possibility of a significant loss of tax revenue when all end benefits were paid tax-free compared to their recommendation in which all benefits would be taxed as they emerged. ${ }^{21}$

The committee also argued that its preferred tax regime would be perceived to be the more natural by taxpayers rather than the artificial situation where the emerging pension is tax-free. If pensions were tax-free, people were bound to worry that some future government could impose a tax again even though logically this does not reflect the capital nature of such flows.

In the event, the government made only minor changes in line with the committee's recommendations and indicated the intention to proceed with the TTE treatment of superannuation saving.

There was a little over 2 years between the announcement of the new regime and its full implementation. The absence of any grandfathering clauses to ease transition meant that the impact of the changes on private superannuation schemes was dramatic. All pension schemes had to be reviewed, and pension levels could be reduced to reflect their new tax-paid status and to allow for the tax on investment income. Many occupational schemes were closed to new members, while others were wound up and the funds distributed. Some were changed from a defined benefit basis to a defined contribution basis.

Existing schemes had until January 1990 to submit proposals to the Government Actuary if they wished to reduce accrued benefits to compensate for the new tax regime. This once-only legislative provision overrode the trust deed, which would not ordinarily permit this to happen without the consent of all affected members. Existing and newly retiring pensioners were to be compensated for the tax on fund earnings and the subsequent reduction in their pensions by being able to take the pension tax-free.

\footnotetext{
${ }^{20}$ Report of the Consultative Committee (1988).

${ }^{21}$ Ibid., p. 21.
} 
There was a widespread misunderstanding concerning the effect of tax-free pensions on final disposable incomes and why pensions had to be reduced. The renegotiation of the defined benefit state sector scheme, the GSF, was particularly acrimonious, with many members seeing the reductions in their benefits as a unilateral attack on their living standards and contractual rights. There were unprecedented marches on Parliament by the police and strikes by prison officers.

Any renegotiated reductions to accrued superannuation benefits were required to be fair between members and to provide no financial advantage to the superannuation fund. Those near or in retirement were to be protected as far as possible. While, strictly speaking, those in retirement or close to retirement would require a much lower reduction in pension benefits than younger members of schemes to compensate for the tax changes, it was deemed to be equitable to have a uniform rate of reduction across the board if the trustees were so to choose.

As it turned out, many schemes in actuarial surplus did not reduce the pensions already being paid much if at all so that pensioners received an immediate increase of disposable income from their pensions of up to 49 per cent depending on their marginal tax rate. The GSF was also required to reduce benefits. In this case, existing pensions were reduced as if the pension was taxed as a primary income ignoring all other forms of income. There were considerable windfall gains for those on the highest marginal tax rate and with the largest pensions. ${ }^{22}$

Not only were the distributional consequences of adopting TTE unfortunate, but the loss of tax revenue was scarcely appropriate in the light of the fiscal problems the government was facing. It was estimated that the revenue forgone over time by the granting of tax-free benefits to those who had saved under a highly tax concessionary regime was of the order of around $\$ 3,000-4,000$ million in present value terms. ${ }^{23}$

The net result of the renegotiation period was that many of those who had already benefitted from the concessionary regime of the past benefitted yet again. The losers were taxpayers generally, and future and current members of existing schemes whose entitlements would be considerably less generous. Ironically, the lost revenue may have eliminated any time advantage that there might have been in bringing forward the receipt of tax from the receipt of the pension to the contributions and fund earnings stages. A one-off tax on accrued capital might have been effective in reducing the windfall gains, as was suggested when similar possible reform was considered in the U.S. $^{24}$

Douglas argued that long drawn out transitional arrangements are seldom fair, they are usually complex and they defer the benefits of the changes being implemented. He believed that any dramatic change in which there are winners and losers was best presented as part of an overall package where personal losses in one area are offset by gains in other areas. But political factors disrupted the reform process so that many of the changes originally envisaged by Douglas were not fully implemented. The full reduction in personal taxes never eventuated as the government backtracked from flat

\footnotetext{
${ }^{22}$ St. John and Ashton (1993, p. 39).

${ }^{23}$ Report of the Consultative Committee (1988).

${ }^{24}$ Munnell (1992).
} 
The Geneva Papers on Risk and Insurance - Issues and Practice

540

Table 2 New Zealand tax schedule for personal income tax

\begin{tabular}{|c|c|c|}
\hline Bracket & Effective marginal tax rate $1988-1996$ & Effective marginal tax rate ${ }^{\mathrm{a}}$ from 2000 \\
\hline$\$ 0-9,500$ & 15 & 15 \\
\hline$\$ 9,501-30,895$ & 28 & 21 \\
\hline$\$ 30,895-38,000$ & 33 & 21 \\
\hline$\$ 38,001-60,000$ & 33 & 33 \\
\hline$\$ 60,000+$ & 33 & 39 \\
\hline
\end{tabular}

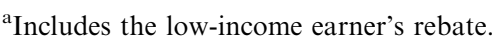

tax, and some other significant features of the wider reforms, including a capital gains tax, were also abandoned. By the time superannuation schemes were renegotiated to allow for the imposition of tax on investment earnings and contributions, the connection between the lower personal tax rates introduced in 1988 and the removal of concessions was largely lost.

The timing of the reforms could hardly have been worse. The December 1987 announcement came just after the New Zealand share market crash and at the beginning of what was to be a prolonged and deep economic recession. Reduced cash flows and the attempts to shift towards more liquid portfolios on the part of major long-term savings institutions intensified the downturn in the property and equities market. Unlike many other countries, share prices were slow to recover after the share market crash, and the share price index (Barclays Index) fell from a peak of 3,800 in October 1987 to around 1,200 by the end of 1990. Attempts to sell assets by institutions in this period may have contributed to the damagingly high interest rates that persisted despite a rapidly reducing rate of inflation. The Consultative Committee had certainly foreseen this possibility as a consequence of the new tax regime. ${ }^{25}$

\section{Backtracking from flat tax}

The tax regime adopted by New Zealand (TTE) for retirement saving works best if the tax rate system is fairly flat. That way, the contributions tax rate applied to employer contributions, the tax rate on fund earnings (the company rate) and the marginal tax rate of contributors will be similar. Neither end-of-year reconciliation nor the imputation of income from tax-paid funds is required. However Douglas's radical and unexpected announcement in late 1987 caused much political bickering within the government itself, and the full package was never implemented the way it was conceived. The flat tax proposal was abandoned and instead, two statutory rates with a low-income rebate were introduced giving three effective marginal tax rates (see Table 2).

Nevertheless until the late 1990s, the tax scale was fairly flat and the tax regime of TTE worked tolerably well. But once the middle-tax rate was lowered, as shown in Table 2, there were big disparities between taxes paid in superannuation funds and the marginal rates actually faced by low- and middle-income earners.

\footnotetext{
${ }^{25}$ Report of the Consultative Committee (1988, p. 26).
} 
Employer fund contributions (under a withholding tax) ${ }^{26}$ and earnings in the fund were taxed at 33 per cent making the regime tax penal for anyone on only a 21 per cent tax rate.

Perversely however, significant tax advantages from saving in employer-sponsored schemes for high-income superannuation fund members were introduced when the top personal tax rate was lifted to 39 per cent in 2000 (see Table 2). Nevertheless, the "salary sacrifice" option for high-income earners to exploit these advantages was not widespread. The Taxation (FBT, SSCWT and Remedial Matters) Act 2000 imposed a fund withdrawal tax (FWT) to reduce the ability of high-income people to use superannuation vehicles as a short-term means of avoiding the 39 per cent rate.

Despite the best endeavour of a working party (TOLIS) ${ }^{27}$ to resolve the marginal tax rate issues, there were no easy answers in determining a suitable proxy rate for either employer contributions or for the taxation of fund earnings. In 2004, a partial solution was introduced so that employers could use the marginal tax rate of the employee for the tax on employer contributions. The option was voluntary and did not address the over-taxation of fund earnings for employees on tax rates of less than 33 per cent. It was not until 2007 that the issue was finally addressed in the raft of dramatic changes described below.

In another tilt to the playing field, superannuation funds paid tax on capital gains where such funds are deemed to be trading rather than "passive". Individuals who invest on their own account are usually exempt from such a tax. In 2004, a report commissioned by government to determine an acceptable tax treatment recommended the removal of capital gains tax on non-passive managed funds to address this anomaly. ${ }^{28}$ The government included this as part of the overall tax changes for investment vehicles to take effect in 2007 as discussed further below.

\section{The "level playing field"?}

New Zealand's tax system is soundly based and among the most neutral in the OECD. Thus, it already provides a good supporting framework for an efficient allocation of resources. ${ }^{29}$

While the OECD has consistently endorsed the New Zealand approach to tax reform, in recent years it has criticised the lack of a capital gains tax. Housing, especially, has remained tax favoured. The New Zealand experience shows that the pursuit of tax neutrality in the treatment of savings is not only difficult to achieve in the absence of flat tax, but is also illusory when other savings vehicles such as housing are taken into account. New Zealanders have proportionately more of their savings tied up in

\footnotetext{
${ }^{26}$ Known as the Specified Superannuation Contribution Withholding Tax (SSCWT).

27 TOLIS (Taxation of Life Insurance and Superannuation) (1997).

28 Stobo (2004).

${ }^{29}$ OECD (2002).
} 
The Geneva Papers on Risk and Insurance - Issues and Practice

542

Table 3 The membership and assets of occupational superannuation schemes (private and public) 1990-2005

\begin{tabular}{ccc}
\hline Year & \% coverage of the labour force & Assets $\$ N Z m$ \\
\hline 1990 & 22.6 & 9,508 \\
2005 & 14.7 & 11,452 \\
\hline
\end{tabular}

Source: Ministry of Economic Development (2006).

housing than in many other countries. Since the tax changes in 1990, the value of housing assets has increased markedly relative to net financial assets. ${ }^{30}$

Significant biases towards investment in housing arise from the non-taxation of the imputed rent in owner-occupied dwellings, the tax-free nature of most capital gains by individuals deemed not to be traders, and the tax regime for rental income that allows deductibility of full nominal mortgage interest and other write-offs such as depreciation with losses deductible against other income. Despite the best endeavours of the McLeod Committee that examined the case for taxing imputed rent and discussed advantages that might flow from a Risk-Free Return Method (RFRM), there has been little political interest in levelling the playing field for housing. ${ }^{31}$

\section{Reintroduction of tax incentives?}

Review taskforces during the 1990s and 2000s supported the voluntary, taxunsubsidised retirement savings regime in New Zealand. ${ }^{32}$ Nevertheless, anxiety persisted about whether New Zealanders save enough, either individually for retirement, or as a nation. New Zealand is heavily reliant on foreign savings with persistently large current account deficits and accumulated overseas debt. While the national saving problem involves more than just the household sector, New Zealanders' poor personal savings habits came under increasing scrutiny. ${ }^{33}$ New Zealand's closest neighbour, Australia also has a national saving problem, but there compulsory private savings had resulted in a dramatic growth of superannuation funds under management and was often cited as a model to follow.

Tax neutrality was one factor contributing to New Zealand's reduced workplace saving. Membership of occupational superannuation schemes (covering the public and private sectors) fell between 1990 and 2005 as Table 3 shows. While assets under management in these schemes increased slowly in nominal terms, they fell substantially in real terms. In 2005 in New Zealand, total pensions funds were only 11.3 per cent of GDP in contrast to 58 per cent in Australia where compulsory superannuation had been implemented in $1993 .{ }^{34}$

${ }^{30}$ Bollard (2004).

${ }^{31}$ McLeod (2001a, b).

32 Periodic Report Group (1997, 2003); Report of the Taskforce on Private Provision for Retirement (1992).

${ }^{33}$ See, for example, Skilling (2005).

${ }^{34}$ OECD (2007). 
A net worth survey showed that mean assets for individuals over 65 was only $\$ 186,000 .{ }^{35}$ With a median of only $\$ 113,000$, the distribution is highly skewed, and on the surface New Zealanders appeared less well prepared for retirement than their counterparts elsewhere. However, Treasury research argued that given the substantial wealth implied by the NZS pension itself, on average, people were saving enough for optimal income smoothing. ${ }^{36}$ A later paper refined this research, but still found little evidence of widespread undersaving. ${ }^{37}$

In 2001, the government reviewed the basis on which private savings are taxed or otherwise encouraged within the parameters that: "... any incentives would have to meet the requirements that they were fiscally affordable, did not crowd out other government spending and added to overall savings levels, rather than merely shifting the form of savings". 38

A range of complex suggestions was made. The Minister of Finance, Dr. Cullen, initially proposed a "parallel option" to the current taxation regime for superannuation, under which contributions continue to be paid from taxed income, investment earnings are tax-free and benefits are partially taxed. This was referred to as TEt (or Taxed, Exempt and partially taxed) compared to the current TTE. There was to be a limit on the annual contributions and a limit on the amount that could accumulate within the scheme. The scheme would be required to lock in the benefits for a period or until a specified age is attained and to provide a portion as a pension.

There were concerns in the industry that compliance would be difficult and would require new schemes distinct from existing schemes. A major, concurrent review of the tax system examined the case for tax incentives in depth, and recommended that they not be reintroduced. ${ }^{39}$

A report of officials noted that it was difficult to ascertain the exact goals government wanted to achieve and that none of the options examined (tTE,TET,TEt) were able to meet all the objectives the government sought. ${ }^{40}$ As in the past when tax incentives were considered it has been difficult not to conclude that the advantages are likely to go to the people who least need an incentive to save, and that overall savings are unlikely to be enhanced. The skewed distribution of financial saving towards the higher income end persuaded the committee that tax concessions would be both highly regressive and ineffective.

On balance, the Treasury report indicated that if a tax incentive were to be reintroduced then a very limited one (with a cap on contributions of $\$ 1,000-2,000$ ) with an upfront incentive was best:

Officials do not suggest that an upfront incentive is likely to make savings more realistic for many low to middle-income households. Such an incentive scheme is

\footnotetext{
${ }^{35}$ Statistics New Zealand (2002). Note $1 €=\$ 1.75$ NZ (June 2007).

${ }^{36}$ Scobie et al. (2004).

${ }^{37}$ Le et al. (2007).

${ }^{38}$ Cullen (2001).

${ }^{39}$ McLeod (2001b).

${ }^{40}$ The New Zealand Treasury (2002).
} 
simpler to promote and explain however, which may increase its utilization amongst households with little to no current savings. While no incentive may be likely to appreciably increase savings, Officials prefer a tTE scheme to a TET or TEt incentive because it would result in fewer harmful distortions to investment patterns, it would have a lower fiscal cost and it would create less room for avoidance and tax planning behaviour. ${ }^{41}$

In other words, Treasury was not enamoured of the idea of reintroducing tax incentives at all. The government continued to discuss saving incentives, but in January 2002 it decided that tax incentives for private saving would not proceed in the current year after all, citing reasons of fiscal tightness.

In February 2002, the National opposition party announced its policy to reintroduce tax incentives. The shape of these would appear to reflect the minimal tTE model proposed by Treasury. But in the May Budget, the Labour government endorsed the status quo of no upfront tax incentives, and later went on to win the election.

The government is not considering upfront tax incentives. These are likely to have to be very large - with fiscal costs running to many hundreds of millions of dollars a year - before they have any desirable effect on overall savings. Their abolition in the mid-1980s represented sensible tax policy on both equity and efficiency grounds. ${ }^{42}$

\section{The un-levelling of the level playing field}

While it appeared that tax concessions were not on the agenda, by 2003 there were calls for a more proactive state intervention in private savings. The Minister of Finance signalled dissatisfaction with the "total remuneration" packages that had become more common:

I do detect a change of attitude. The 1990s were a high watermark for individualism. A part of that was the rise of the idea of the total remuneration package. Employers recruited on a set fee for service and the worker did what he or she decided they wanted to with the wage. While this is fine in theory, there is a growing body of research that suggests that the handsoff approach works against some of that total remuneration going into long term saving. ${ }^{43}$

A new "State Sector Retirement Savings Scheme" commenced in 2004 as a portable defined contribution scheme in which the government as employer matched contributions up to 3 per cent of salary. A wide choice of investment styles,

\footnotetext{
${ }^{41}$ Ibid., p. 1.

${ }^{42}$ Minister of Finance (2002).

${ }^{43}$ Cullen (2003).
} 
risk/return options and fee structures was offered from a limited list of providers. The government appeared to consider the new scheme as a role model for private sector employees, but how private sector employers could match a subsidy sourced from the general taxpayer was not clear. In the middle of 2004, the government appointed a working group to report on the design of a generic workplace savings product. ${ }^{44}$ There were many difficult issues, such as whether there should be automatic enrolment, how part-time and casual workers might be included, rules around early withdrawal, management and approval of schemes and how all this could be achieved in a taxneutral environment.

While the working group assumed that the government would not introduce any tax incentives for the generic product, it was clear that "sweeteners" as they are called in the report were likely to be necessary. Critics, such as the Association of Superannuation Funds in New Zealand argued that any such incentives would undermine existing employment-based schemes and would be a costly mistake, both ineffective in substantially increasing saving and cumbersome to administer.

\section{The KiwiSaver}

The predicted economic slowdown of the mid-2000s failed to materialise as the sustained housing boom, fed by the willingness of banks to borrow abroad, kept confidence high. A worrying scenario of a tight monetary policy to contain the economic boom, leading to high interest and high exchange rates thus exacerbating the current account deficit and overseas debt was being played out. The current account deficit approached over 9 per cent of GDP with net international financial liabilities at around 85 per cent GDP, leading to evermore strident calls for households to save more.

The 2005 budget announced that a work-based saving scheme, KiwiSaver, would be introduced in 2007 (see Box 1). The key premise of KiwiSaver is that people are more likely to commit to saving regularly if they are automatically enrolled rather than deciding whether to "opt in". Initially, the only government subsidy was a flat $\$ 1,000$ "sweetener" (and a modest annual fee subsidy) that eschewed the problems of the regressivity of tax concessions, thus enabling the TTE tax regime to remain unaffected.

The legislation was subject to the normal submissions through the select committee process but when the bill was finally reported back in 2006, some key features of KiwiSaver had been changed. Of particular significance, it had been decided that employer contributions that matched employee contributions up to 4 per cent of gross income would be exempt from the withholding tax (SSCWT). The legislative effect for this was not in the KiwiSaver Act 2006 itself but in the Taxation (Annual Rates, Savings Investment and Miscellaneous Provisions) Bill, going through the House at the same time, and appeared to be the result of compromise in a Mixed Member Proportional (MMP) parliamentary system.

Exactly as would be predicted this was the thin end of the wedge. The Association of Superannuation Funds in New Zealand argued that there was a serious risk that many

\footnotetext{
${ }^{44}$ Savings Product Working Group (2004).
} 


\section{Box 1 KiwiSaver}

- KiwiSaver is a voluntary, work-based savings scheme administered by the Inland Revenue Department using the existing PAYE (pay as you earn) tax system. Employees are automatically enrolled into KiwiSaver when they start a new job. They have the second to eighth week of employment to "opt-out" and must advise their employer of their decision.

- Scheme enrolment is not automatic for workers under 18 , or those employed less than 4 weeks, or for existing employees. They may join if they wish. Self-employed people, beneficiaries and children can join but make payments directly to the scheme provider.

- Employees' contributions start from the first pay day with an employer. Deductions from wages are at a rate of 4 per cent of gross salary, unless the individual opts for the higher rate of 8 per cent. Matching contributions up to 4 per cent by the employer are tax-free.

- In the 2007 budget, a matching tax subsidy of \$20 a week was announced for employees' contributions and a compulsory 4 per cent contribution from employers to be phased in over 4 years, matched with another $\$ 20$ a week-tax subsidy. The top rate of tax on fund earnings in PIE schemes was reduced to 30 per cent.

- Funds are held by Inland Revenue for an initial 3-month period during which the employee can seek financial advice and select a fund provider. Savers will be able to select their own fund and can change fund providers, but can only have one provider at any time. Those who do not specify a fund will be randomly allocated to a default provider.

- Savings are "locked in" (i.e., will not be accessible) until the age of eligibility for NZ Superannuation, currently 65, except in cases of: financial hardship, permanent emigration, serious illness or after a minimum of 3 years or to contribute towards a deposit on a first home. However, after a minimum of 12-month contribution period, savers can stop contributions for up to 5 years by applying for a "contributions holiday". Contributions resume at the end of the 5 years unless the individual applies for a further "contributions holiday".

- Existing superannuation schemes have the option of converting to KiwiSaver, subject to certain criteria. Members of other schemes may choose to open a KiwiSaver account, instead of or as well as, their existing scheme. Alternatively, an existing scheme may become a "complying fund" that captures the tax incentives offered to KiwiSaver schemes but not the "\$1000 kickstart" nor the annual fee subsidy.

- The automatic enrolment provisions will not apply in workplaces where the employer is already running a work-based scheme, provided the scheme is portable, open to all new permanent employees, and has a contribution rate from employer and employee of at least 4 per cent each. This qualifies the employer to be exempt.

- The Government will make an upfront contribution of $\$ 1,000$ plus $\$ 40$ for fees per person, to be "locked in" until the recipient reaches the age of eligibility for NZS or for 5 years, whichever is the greater, provide a fee subsidy, offer a first-home deposit subsidy of $\$ 1,000$ per year of membership in the scheme, up to a maximum of $\$ 5,000$ for 5 years.

Source: derived from http://www.treasury.govt.nz/kiwisaver/.

existing superannuation schemes would be wound up, undermining the government's goal of increased saving. Thus almost immediately, a further Supplementary Order paper extended similar tax privileges to all employer superannuation schemes that met lock-in provisions. Cabinet papers released under the Official Information Act noted there was a high risk of pressure for yet further extensions to employee contributions and to the self-employed. ${ }^{45}$ Furthermore, it was acknowledged that the extension to

${ }^{45}$ Inland Revenue Department (2006). 
other schemes had little to do with the goal of increasing new saving as the effect would be to subsidise existing saving.

While there appeared to be little, or no, in-depth analysis of the regressivity of the reintroduction of tax incentives, the IRD noted that the higher the employee's salary the higher the benefit, and that "... the benefit of the $\$ 1,000$ government contribution to KiwiSaver and the fee subsidy pale over time in comparison with the benefit of the tax exemption". 46

Treasury officials were clearly concerned about their potential cost: "The fiscal risks of a wide extension of the SSCWT exemption (and other KiwiSaver incentives) are very considerable". 47

A housing subsidy had been made available through KiwiSaver for first home buyers (see Box 1); but in addition, a mortgage diversion scheme was also introduced late in the piece despite select committee scrutiny that had rejected it. Under this scheme, after 1 year, up to half of the employee's own KiwiSaver contributions can be directed to mortgage repayment. Given that a key concern that promoted KiwiSaver in the first place was overinvestment in housing, providing mortgage repayments from what was intended to be retirement savings appeared somewhat counterintuitive.

The introduction of KiwiSaver was timed to coincide with the reform of the taxation of collective investment vehicles including superannuation schemes. The intent was to retain the tax-paid nature of superannuation schemes, but to align the proxy tax rate more closely with the tax rate of the individual investor. Unfortunately, as the previous TOLIS exercise showed, there is no easy way to do this accurately without an end-of-year reconciliation. The final legislation reflected this dilemma - erring on the side of generosity to the individual and thus opening the gates to avoidance activity.

KiwiSaver schemes are expected to be "Portfolio Investment Entities" (PIEs), where a member who earns under $\$ 38,000$ from other sources but whose total income including PIE income is under $\$ 60,000$ can opt for a 19.5 per cent rate. In effect, this could mean $\$ 60,000$ of PIE income can be taxed at only 19.5 per cent. If the member earns more than $\$ 38,000$ in taxable pay, or more than a combined $\$ 60,000$ including the PIE income, the whole of the PIE income is taxed at the alternative higher PIE rate originally set at 33 per cent, but later to be lowered to 30 per cent. Thus there are not inconsiderable rewards for restructuring the way in which earned income is received.

Other avenues for avoidance of tax could be expected to emerge over time. For example, the ability and incentive for employees to salary sacrifice into superannuation schemes generally, together with the lack of full accounting for PIE income, means that eligibility for income-tested government-provided supplements could be enhanced. For instance, an extensive programme of Families Tax Credits now applies a long way up the income distribution, ${ }^{48}$ providing a further 20 per cent return on a salary sacrifice arrangement. Thus a family on $\$ 120,000$ (about three times average earnings) with several children may save $\$ 590$ for every $\$ 1,000$ of gross income diverted to an employer contribution to KiwiSaver. A recent policy has made student

\footnotetext{
${ }^{46} \mathrm{Ibid}$.

${ }^{47}$ Ibid.

${ }^{48}$ See St. John (2006a).
} 
loans interest-free, so that income contingent repayments can be profitably reduced and access to income-tested state welfare benefits enhanced.

\section{Enhanced KiwiSaver 2007}

Once the principle of tax neutrality was breached by the announcement of tax-free matching employer contributions, the slippery slide had begun. Why then not a tax break for employee contributions, and why not compulsion? In the May Budget (just 6 weeks before KiwiSaver was to begin) it was announced that tax subsidies would indeed be dramatically extended as outlined in Box 1, and employer contributions made compulsory for those employees in the scheme. The top rate of the PIE tax regime was reduced to 30 per cent, creating an ever-bigger gap between the top-income tax rate and the tax on investments in PIEs.

The new matching tax subsidies that apply to the first $\$ 20$ contributed by the employee and employer are less regressive than pure tax exemptions; however, the cost is high. The New Zealand Treasury estimates that by 2011, the fiscal cost will be $\$ 1.2$ billion, while the effect on household saving is expected to be only $\$ 1.1$ billion. ${ }^{49}$

\section{Discussion and lessons for other countries}

Tax incentives for saving for retirement have been traditional in Western societies. Their negative effects have been well documented ${ }^{50}$ including their regressivity, their ineffectiveness in increasing saving, their complexity and the costs of their regulation and administration, their gender bias, and their lack of transparency. New Zealand alone has experimented with a different way.

The costs of moving to a TTE regime were high as has been outlined. The rewards of simplicity and fairness were only partially realised, however, largely because of the failure to deal with housing. Investment in housing remained tax-advantaged, while saving in superannuation schemes was often treated inappropriately at the individual level. Speculation in housing contributed to a worrying current account deficit and high overseas indebtedness, fuelled in turn by high interest rates and an overvalued exchange rate. In a scramble to address this problem, together with an unwillingness to confront the housing market directly, the previous highly principled approach to tax matters was relegated to second place.

In 2005, a government discussion document claimed:

... it is important that the tax rules for investment income operate efficiently and that investors' decisions are not distorted by different tax treatments for income from investments that are similar in nature.... ${ }^{51}$

But the policy direction had taken New Zealand a long way from this ideal just 2 years later (see Box 2). The 2007 changes to KiwiSaver enhance the tax advantages of

\footnotetext{
${ }^{49}$ The New Zealand Treasury (2007).

${ }^{50}$ See, for example, Sinfield (2000).

${ }^{51}$ New Zealand Government (2005).
} 
Box 2 Timeline for changes to the tax regime for saving for retirement in superannuation schemes (including KiwiSaver schemes) in New Zealand

\begin{tabular}{|c|c|c|c|c|}
\hline Years & Employer contributions & Employee contributions & Fund earnings & Final withdrawals \\
\hline Pre-1988 & $\begin{array}{l}\text { Lump sum - tax-free to ceiling } \\
\text { Pension - tax-free }(E)\end{array}$ & To ceiling, tax-free (E) & Tax-free $(\mathrm{E})$ & $\begin{array}{l}\text { Lump-sum tax-free }(E) \\
\text { Pension taxed }(T)\end{array}$ \\
\hline $\begin{array}{l}\text { From } 1 \text { July } 2007 \text { - KiwiSaver } \\
\text { or complying fund only }\end{array}$ & $\begin{array}{l}\text { Tax-free to } 4 \% \text { employee's } \\
\text { gross pay (voluntary) } \\
\text { Employer gains matching tax } \\
\text { subsidy up to } \$ 20 \text { a week }\end{array}$ & $\begin{array}{l}\text { Taxed at MTR but } \\
\text { matching tax subsidy } \\
\text { up to } \$ 20 \text { a week }\end{array}$ & $\begin{array}{l}\text { Taxed at } 19.5 \text { or } 33 \% \\
\text { as a proxy for MTR of } \\
\text { employee }\end{array}$ & Tax-free lump sum \\
\hline $\begin{array}{l}2008 \text { KiwiSaver or } \\
\text { complying fund only }\end{array}$ & $\begin{array}{l}1 \% \text { of employee's gross pay } \\
\text { (compulsory for members) } \\
\text { Employer gains matching tax } \\
\text { subsidy up to } \$ 20 \text { a week }\end{array}$ & $\begin{array}{l}\text { Taxed at MTR but } \\
\text { matching tax subsidy } \\
\text { up to } \$ 20 \text { a week }\end{array}$ & $\begin{array}{l}\text { Taxed } 19.5 \text { or } 30 \% \text { as a } \\
\text { proxy for MTR of employee }\end{array}$ & Tax-free lump sum \\
\hline $\begin{array}{l}2009 \text { KiwiSaver or } \\
\text { complying fund only }\end{array}$ & $\begin{array}{l}2 \% \text { of employee's gross pay } \\
\text { (compulsory for members) } \\
\text { Employer gains matching tax } \\
\text { subsidy up to } \$ 20 \text { a week }\end{array}$ & $\begin{array}{l}\text { Taxed at MTR but } \\
\text { matching tax subsidy } \\
\text { up to } \$ 20 \text { a week }\end{array}$ & $\begin{array}{l}\text { Taxed } 19.5 \text { or } 30 \% \text { as a } \\
\text { proxy for MTR of employee }\end{array}$ & Tax-free lump sum \\
\hline $\begin{array}{l}2010 \text { KiwiSaver or } \\
\text { complying fund only }\end{array}$ & $\begin{array}{l}3 \% \text { of employee's gross pay } \\
\text { (compulsory for members) } \\
\text { Employer gains matching tax } \\
\text { subsidy up to } \$ 20 \text { a week }\end{array}$ & $\begin{array}{l}\text { Taxed at MTR but } \\
\text { matching tax subsidy } \\
\text { up to } \$ 20 \text { a week }\end{array}$ & $\begin{array}{l}\text { Taxed } 19.5 \text { or } 30 \% \text { as a } \\
\text { proxy for MTR of employee }\end{array}$ & Tax-free lump sum \\
\hline $\begin{array}{l}2011 \text { KiwiSaver or } \\
\text { complying fund only }\end{array}$ & $\begin{array}{l}4 \% \text { of employee's gross pay } \\
\text { (compulsory for members) } \\
\text { Employer gains matching tax } \\
\text { subsidy up to } \$ 20 \text { a week }\end{array}$ & $\begin{array}{l}\text { Taxed at MTR but } \\
\text { matching tax subsidy } \\
\text { up to } \$ 20 \text { a week }\end{array}$ & $\begin{array}{l}\text { Taxed } 19.5 \text { or } 30 \% \text { as a } \\
\text { proxy for MTR of employee }\end{array}$ & Tax-free lump sum \\
\hline
\end{tabular}


belonging to such an extent that many existing schemes are expected to close or become "complying" schemes over time. The departures from tax neutrality were accelerated by compromises in an MMP environment and have appeared easy to sell to an unsophisticated public. The financial services industry has been buoyed by the prospect of new business and has perpetuated the popular illusion that such tax concessions will help to solve the saving problem.

While the original reforms that promoted tax neutrality were part of an overall coherent package, recent changes have been introduced in a piecemeal process and illustrate the dangers of opening the floodgates even a little. As discussed, KiwiSaver led to the series of subsequent adjustments including direct matching tax subsidies for employee and employer contributions up to a ceiling, has opened avenues for tax avoidance in collective investment vehicles (PIEs) and may lead to full compulsion.

In other countries, tax incentives usually have one clear redeeming feature; they may allow prescription of the nature of the final benefit. Provision of income via a taxable pension or an annuity can give society some pay-back for foregoing tax revenue in the accumulation process. New Zealand had a unique opportunity with a tax-neutral regime to design an explicit subsidy to recognise the gains to society from annuitisation with few of the disadvantages of traditional tax incentives. ${ }^{52}$ This opportunity is now passing while New Zealand runs the dangers of an ETE regime, with lump sums alone coming out of KiwiSaver and other tax-advantaged schemes.

The New Zealand retirement system has been built on the provision of a generous universal pension for all without any means test. If the private savings of the well-off become tax-subsidised, however, such largesse may be called into question. The advantages of simple fully universal pension may eventually be a casualty of the reversal in tax policy. The hard-won gains of the 20-year experiment have been lost, not with "a bang but with a whimper".

\section{References}

Bollard, A. (2004) 'What's happening in the property sector?', Reserve Bank of New Zealand: Bulletin 67(3): 37-46.

Cullen, M. (2001) Superannuation Tax Regime, Speech to Grey Power, Wellington, Office of the Minister of Finance, New Zealand Government, 18 May 2001.

Cullen, M. (2003) NZ Super Fund close to point of no-return, paper presented at the Savings Summit, Wellington.

Douglas, R. (1987) Changes to the Personal Tax Scale, Minister of Finance Press Release, 17 December.

Easton, B. (1997a) The Commercialisation of New Zealand, Auckland, NZ: Auckland University Press.

Easton, B. (1997b) In Stormy Seas. The Post-War New Zealand Economy, Dunedin, NZ: University of Otago Press.

Fergusson, D., Hong, B., Horwood, J., Jensen, J. and Travers, P. (2001) Living Standards of Older New Zealanders. A Technical Account, Wellington, NZ: Ministry of Social Policy.

Hughes, G. (2005) 'Pension tax reliefs and equity', in J. Stewart (ed) For Richer, For Poorer. An Investigation of the Irish Pension System, Dublin: Betaprint Limited.

Inland Revenue Department (2006) Tax Policy Report: Fiscal Implications of the SSCWT Exemption for KiwiSaver, Released under the Official Information Act, 17 July.

\footnotetext{
${ }^{52}$ St. John (2006b)
} 
Johnson, P. (1999) Older Getting Wiser, London: Institute of Chartered Accountants in England and Wales.

Le, T., Scobie, G. and Gibson, J. (2007) Are Kiwis Saving Enough for Retirement? Preliminary Evidence from SOFIE, paper prepared for the Eighth Annual SuperFunds Summit, Wellington, 15-16 March, New Zealand Treasury.

McCashin, A. (2005) 'The state pension-towards a basic income for the elderly?', in J. Stewart (ed) For Richer, For Poorer, Dublin: Ashfield Press.

McLeod, R. (2001a) The Issues (No. Tax Review 2001), Wellington: New Zealand Government.

McLeod, R. (2001b) Tax Review 2001. Final Report, Wellington: New Zealand Government.

Minister of Finance (2002) 'December Economic and Fiscal Update 2002', from http://www.treasury. govt.nz.

Ministry of Economic Development (2006) 'Report of the Government Actuary for the Year Ended 30 June 2006', accessed at http://www.isu.govt.nz.

Ministry of Social Development (2005) 'Social Report Indicators for Low Incomes and Inequality Update from the 2004 Household Economic Survey', from http://www.msd.govt.nz/work-areas/cross-sectoralwork/indicators-for-low-incomes-and-inequality.html.

Ministry of Social Development (2006) New Zealand Living Standards 2004, Wellington: Ministry of Social Development.

Munnell, A. (1992) 'Current taxation of qualified pension plans: Has the time come?', New England Economic Review (March): 12-25.

New Zealand Government (2005) Taxation of Investment Income. The Treatment of Collective Investment Vehicles and Offshore Portfolio Investments in Shares, Wellington: Policy Advice Division of the Inland Revenue Department.

OECD (2002) Economic Surveys: New Zealand (Country Reviews), Paris: OECD.

OECD (2007) The OECD in Figures, Paris: OECD.

Periodic Report Group (1997) 1997 Retirement Income Report: A Review of the Current Framework - Interim Report, Wellington, NZ: GP Print.

Periodic Report Group (2003) Retirement Income Report 2003, Wellington, NZ: GP Print.

Preston, D. (2001) 'Retirement Income in New Zealand: The Historical Context', from http:// www.retirement.org.nz.

Report of the Consultative Committee (1988) Tax Treatment of Superannuation, Office of the Consultative Committee on Superannuation, Life Insurance and Related Areas, Wellington.

Report of the Taskforce on Private Provision for Retirement (1992) Private Provision for Retirement: The Options, Wellington: The Taskforce on Private Provision for Retirement.

Savings Product Working Group (2004) 'A Future for Work-Based Savings in New Zealand', from http:// www.beehive.govt.nz/Documents.

Scobie, G., Gibson, J. and Le, T. (2004) Saving for retirement: New evidence for New Zealand, New Zealand Treasury working paper no. 04/12, New Zealand Treasury, Wellington.

Sinfield, A. (2000) 'Tax benefits in non-state pensions', European Journal of Social Security 2: 137-167.

Skilling, D. (2005) Home is Where the Money Is: The Economic Importance of Savings, (No. 2005/1), New Zealand Institute, Auckland.

St. John, S. (2005) Pensions taxation and retirement incomes in New Zealand, Seminar paper no. SP2005-08, The Economic and Social Research Institute, Dublin.

St. John, S. (2006a) 'Child poverty: Lessons from New Zealand', European Journal of Social Security (EJSS) 8: 299-316.

St. John, S. (2006b) The Policy Implications of Decumulation in Retirement in New Zealand. A Background Paper Setting Out the Issues Prepared for the Retirement Commission, Wellington: Retirement Commission.

St. John, S. and Ashton, T. (1993) Private Pensions in New Zealand: Can They Avert the Crisis?, Wellington: Institute of Policy Studies.

St. John, S. and Gran, B. (2001) 'The world's social laboratory: Women friendly aspects of New Zealand pensions', in J. Ginn, D. Street and S. Arber (eds) Women, Work and Pensions, Buckingham: Open University Press. 
St. John, S. and Willmore, L. (2001) 'Two legs are better than three: New Zealand as a model for old age pensions', World Development 29: 1291-1305.

Statistics New Zealand (2002) The Net Worth of New Zealanders. Data From the 2001 Household Savings Survey. Standard Tables and Technical Notes, Wellington: Household Economic Statistics Division, Statistics New Zealand.

Stobo, C. (2004) 'Towards Consensus on the Taxation of Investment Income. Report to the Minister of Finance and Revenue', from http://www.taxpolicy.ird.govt.nz.

The New Zealand Treasury (2002) Treasury Report: Saving Incentive Options, Consultation and Analysis, Wellington: The New Zealand Treasury.

The New Zealand Treasury (2007) Budget Economic and Fiscal Update, Wellington: The New Zealand Treasury.

TOLIS (1997) Report to Ministers from the Working Group on the Taxation of Life Insurance and Superannuation Fund Savings, Wellington: TOLIS.

\section{About the Author}

Susan St. John is the Co-Director of the Retirement Policy and Research Centre, Economics Department, Business School University of Auckland, where she also teaches Public Policy and Public Economics. 